\title{
Paulo Freire: \\ o educador proibido de educar
}

\author{
Paulo Freire: \\ the teacher prohibited to teach
}

Paulo Freire:

el educador que está prohibido educar

ANDRÉIA NUNES MILITÃO*

Universidade Estadual de Mato Grosso do Sul, Dourados- MS, Brasil.

\section{CRISTIANO AMARAL GARBOGGINI DI GIORGI ${ }^{* *}$}

Universidade do Oeste Paulista, Presidente Prudente- SP, Brasil.

\begin{abstract}
RESUMO: O artigo objetiva desvelar porque Paulo Freire tornou-se alvo de ataques de setores conservadores que tentaram interditar suas ideias e práticas. Tem-se como questão central: Por que Paulo Freire incomoda? A quem? O que revelam os discursos contra o autor? Por que interditar Paulo Freire? Freire foi interditado por setores conservadores no passado ditatorial, levando-o ao exílio e à desconstrução de suas ideias com o encerramento de programas de alfabetização. Hoje, o movimento Escola Sem Partido (EsP) elegeu Paulo Freire como alvo. As obras freireanas, documentos nacionais e documentos produzidos pelo EsP constituem fontes primárias que ajudam a desvelar o problema. As ofensivas a Paulo Freire expressam o ataque a própria democracia.

Palavras-chave: Paulo Freire. Democracia. Escola sem Partido.
\end{abstract}

* É graduada em História e Pedagogia. Possui mestrado em História e doutorado em Educação, ambos pela Universidade Estadual Paulista Júlio de Mesquita Filho. É professora da Universidade Estadual de Mato Grosso do Sul, docente do Programa de Pós-Graduação em Educação da Universidade Federal da Grande Dourados e líder do Grupo de Estudos e Pesquisa Políticas Educacionais e Formação de Professores (GEPPEF). E-mail: <andreianunesmilitao@gmail.com>.

** É graduado em Física pela Universidade de São Paulo, mestre em Educação pela Pontifícia Universidade Católica de São Paulo e doutor em Educação pela Universidade de São Paulo. Foi professor titular da Universidade Estadual Paulista Júlio de Mesquita Filho e, atualmente, é docente na Universidade do Oeste Paulista. E-mail:<utopico92@gmail.com>. 


\begin{abstract}
The article aims to reveal the reason why Paulo Freire became the target of conservative sectors that tried to interdict his ideas and practices. The central questions are: Why is Paulo Freire a bother? Whom does he bother? What do the discourses against the author reveal? Why interdict Paulo Freire? Freire got banned by conservative sectors in the dictatorial past, leading him into exile and the dismantling of his ideas with the end of literacy programs. Nowadays, the School without Party movement (EsP) has elected Paulo Freire as target. Freirean works, national documents, and documents produced by the EsP are taken as primary sources to help on unveiling the problem. The offensives against Paulo Freire express the attack on democracy itself.
\end{abstract}

Keywords: Paulo Freire. Democracy. School without Party.

RESUMEN: El artículo tiene como objetivo revelar por qué Paulo Freire se convirtió en blanco de ataques de sectores conservadores que intentaron prohibir sus ideas y prácticas. La pregunta central es: ¿Por qué incomoda Paulo Freire? / ¿A quién? ¿Qué revelan los discursos contra el autor? ¿Por qué prohibir a Paulo Freire? Freire fue proscrito por sectores conservadores en el pasado dictatorial, lo que lo llevó al exilio y a la deconstrucción de sus ideas con el fin de los programas de alfabetización. Hoy, el movimiento Escola Sem Partido(ESP) ha elegido a Paulo Freire como objetivo. Las obras freireanas, los documentos nacionales y los documentos producidos por la ESP son fuentes primarias que ayudan a develar el problema. Las ofensivas contra Paulo Freire expresan el ataque a la democracia misma.

Palabras clave: Paulo Freire. Democracia. Escuela Sin Partido.

\title{
Introdução
}

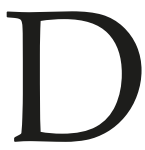

epreende-se que em duas temporalidades diferentes - 1964 e anos 2000 - Paulo Freire passa a ser alvo preferencial de grupos conservadores. De comum, os dois períodos históricos têm a instituição de um Estado Policial sob a lógica da criminalização daqueles que manifestam pensamentos dissonantes, notadamente o movimento social, os sindicatos, os partidos políticos progressistas, entre outros. A esse respeito, Frigotto (2017, p. 30) assevera “Daí deriva-se para o que é científico neutro e deve ser ensinado nas escolas". 
No tempo presente, marcado pelo golpe jurídico-midiático-parlamentar, avulta-se "A relação entre os mecanismos jurídicos formais que sustentaram e consumaram o golpe e as teses do Escola sem Partido de incriminar os docentes tem na delação, com base no arrependimento ou discordância moral, seu fundamento mais ardiloso e perverso" (FRIGOTTO, 2017, p. 30).

O que propugna o Escola sem Partido não liquida somente a função docente, no que a define substantivamente e que não se reduz a ensinar o que está em manuais ou apostilas, cujo propósito é de formar consumidores. A função docente no ato de ensinar tem implícito o ato de educar. Trata-se de, pelo confronto de visões de mundo, de concepções científicas e de métodos pedagógicos, desenvolver a capacidade de ler criticamente a realidade e constituírem-se sujeitos autônomos. A pedagogia da confiança e do diálogo crítico é substituída pelo estabelecimento de uma nova função: estimular os alunos e seus pais a se tornarem delatores (FRIGOTTO, 2017, p. 31).

Intenta-se desvelar por que Paulo Freire tornou-se o foco preferencial do movimento Escola sem Partido (EsP). Para problematizar a questão, este texto foi organizado em três partes. A primeira seção procura desvelar as ações e as intencionalidades do EsP no campo educacional para compreender como fundamentam as críticas a Paulo Freire. Na sequência, problematiza-se o significado em Freire da não neutralidade da educação e a sua defesa intransigente da acepção "educação é política". O terceiro item examina Paulo Freire como alvo preferencial do EsP em dois contextos históricos. Ao final, tecem-se algumas conclusões, que associam as ofensivas a Paulo Freire, em ambos os contextos, à ofensiva contra a própria democracia, posto que as formulações freireanas assentam-se neste pressuposto.

\section{O movimento Escola sem Partido: ações e intencionalidades}

A análise do movimento pedagógico autodenominado Escola sem Partido não deve se restringir às questões educacionais, posto que sua incidência ultrapassa os muros escolares. Nesta perspectiva, Frigotto (2017, p. 19) considera ser necessário "um olhar na perspectiva da historicidade dos fatos e fenômenos, vale dizer, das determinações mais profundas e menos visíveis que os constituem, indica-nos que se trata de algo já sedimentado nas relações sociais".

Frigotto (2017) localiza o viés ideológico e político do Escola sem Partido, caracterizado por:

Um sentido autoritário que se afirma na criminalização das concepções de conhecimento histórico e de formação humana que interessam à classe trabalhadora e em posicionamentos de intolerância e ódio com os movimentos sociais, em particular o Movimento dos Trabalhadores Sem Terra (MST). Mas também, o ódio aos movimentos de mulheres, de negros e de lésbicas, gays, bissexuais, travestis e transgêneros (FRIGOTTO, 2017, p. 18). 
Amalgamado à concepção de Estado Policial, o movimento Escola Sem Partido recorreu à "[...] judicialização da relação entre professores e alunos, tendo, em seguida, passado a pressionar as assembleias estaduais e municipais por projetos de leis que legitimassem suas ideias, processo que vem se intensificando" (MACEDO, 2017, p. 508). ${ }^{1}$

Com foco na educação básica e no ensino superior, os organizadores do $\mathrm{EsP}^{2}$ justificam sua criação "para dar visibilidade a um problema gravíssimo que atinge a imensa maioria das escolas e universidades brasileiras: a instrumentalização do ensino para fins ideológicos, políticos e partidários". A ação do EsP centra-se no controle dos professores, sem apresentar quaisquer diagnósticos de questões educacionais e/ou propostas para sua melhoria.

Pode-se localizar em meados dos anos 1980 algumas das ideias que servem de base ao EsP. Excertos do livro "Social Democracia e Educação: teses para discussão" Guiomar Namo de $\mathrm{Mello}^{3}$ permitem-nos localizar resistências à Paulo Freire e a suas ideias nas instituições educacionais, traduzindo, portanto, a ascendência do movimento Escola sem Partido ${ }^{4}$. Nesta obra, a autora, que já havia ocupado o cargo de secretária municipal de educação da cidade de São Paulo e exercido o mandato de deputada estadual pelo Partido do Movimento Democrático Brasileiro (PMDB), autodefine-se como "A educadora, mulher de vida pública, militante político-partidária [...]". Ainda na apresentação do livro destaca:

Outra provocação que levou à produção destes textos foi o Programa do PSDB Partido da Social Democracia Brasileira, de cuja fundação e organização venho participando e cuja identidade política tenho tentado ajudar a construir. As teses propostas neles existentes pretendem ser uma contribuição a esse partido, na formulação de um projeto político-social-democrata para a educação brasileira (MELLO, 1990, p. 14).

Ao encampar a proposta de "Revolução Educacional na perspectiva da Social Democracia”, Mello (1990, p. 18) propõe “[...] limpar o debate educacional de invencionices populistas como a chamada escola de tempo integral, bem como retirar esse debate do emaranhado ideológico que tem tomado tempo e energia [...]”. Mello (1990) ressignifica, a partir dos conceitos da social democracia, os termos e propostas educacionais originárias do campo progressista.

Na perspectiva da autora, a educação escolar deve se restringir à transmissão de conhecimentos disciplinares. Contrapondo-se à Paulo Freire, assevera: "Não cumpre à escola formar militantes políticos, nem ela tem poder para determinar o destino social, a ideologia ou o projeto político de cada um" (MELLO, 1990, p. 31).

Em entrevista publicada neste número da Revista Retratos da Escola (2020), Dagmar Zibas destaca que "esse embrião da 'escola sem partido' estava se formando no 
Pós-Graduação da PUC/SP em 1980, e sua representante maior era a Prof. Dra. Guiomar Namo de Mello".

Localiza-se entre os esforços do EsP para consolidar seu projeto educacional conservador a iniciativa de emplacar a Ideia Legislativa n⿳0 90.310 sob o título "Revogação da lei que institui Paulo Freire patrono da educação brasileira (Lei n. 12612/2012)" a partir do argumento: "Paulo Freire é considerado filósofo de esquerda e seu método de educação se baseia na luta de classes, o sócio construtivismo é a materialização do marxismo cultural, os resultados são catastróficos e tal método já demonstrou em todas as avaliações internacionais que é um fracasso retumbante", proposta subscrita pela estudante Stefanny Papaiano.

A Comissão de Direitos Humanos e Legislação Participativa ${ }^{6}$ designou a senadora Fátima Bezerra, em 11 de outubro de 2017, como relatora da Sugestão no 47 de 2017 do Programa e-Cidadania. Normatizado pela Resolução do Senado Federal (RSF) no 19 de 2015, propunha a invalidação da Lei que institui Paulo Freire como patrono da educação brasileira. O Relatório expressa a preocupação de recuperar "[...] aspectos relevantes de sua vida e obra, de modo a evitar que, em pleno século XXI, o seu pensamento seja alvo de censura ideológica, a exemplo do ocorrido durante a ditadura civil-militar" (CDH, 2017, p. 3). Defende, ainda, que "A escola não pode negar a realidade na qual está inserida. Ela tem a competência de significar essa realidade, de desvendá-la. E o educador não pode ser vigiado ou criminalizado como pretende este absurdo que é a 'Lei da Mordaça"' (CDH, 2017, p. 9).

Em reação ao movimento conservador que propunha expurgar Paulo Freire da educação nacional, iniciando-se pela retirada da sua condição de patrono da educação brasileira, o Coletivo Paulo Freire Por Uma Educação Democrática lançou em 16 de outubro de 2017 o Manifesto em defesa do legado freireano e da consagração de Paulo Freire como Patrono da Educação Brasileira. De acordo com o manifesto, "Cassar de Paulo Freire o título de "Patrono da Educação Brasileira", recebido in memoriam, representa impor a ele e à sua obra uma espécie de segundo exílio, tão violento quanto o primeiro (1964-1980), levado a cabo pela Ditadura Civil-Militar (1964-1985)".

Na tentativa de inviabilizar a escola pública, o EsP passa a operar a partir de duas estratégias, que combinam o embate no plano discursivo e a busca da interdição via judicial de elementos substantivos do currículo, embargando também a atuação dos professores. Ximenes e Vick (2020) analisam a recente decisão do Supremo Tribunal Federal acerca do movimento EsP. Para os autores, a decisão judicial encerra uma disputa jurídica sobre a censura nas escolas.

OSTF decidiu dar fim a uma das mais danosas farsas jurídicas da atualidade: as legislações antigênero na educação, que proliferam no Brasil desde 2014. Disseminadas por movimentos reacionários e grupos fundamentalistas junto aos Legislativos, essas normas e os debates parlamentares que as antecedem dão suporte institucional à cruzada antigênero e à censura nas escolas, servindo 
de plataforma ao pânico moral e suas consequências políticas e sociais. ${ }^{1}$ Há anos contestadas em mais de uma dezena de ações judiciais, desde fins de abril deste ano tais normas vêm sendo julgadas e declaradas inconstitucionais, uma a uma, por unanimidade, no discreto Plenário Virtual do STF (XIMENES; VICK, 2020, s/p).

Ximenes e Vick (2020) localizam no mesmo período "a tramitação do primeiro projeto de lei nacional identificado ao Escola sem Partido (EsP), o PL n. 7.180/2014, que foi seguido do PL n. 867/2015, este um protótipo dos projetos apresentados no estado e no município do Rio de Janeiro pelos irmãos Flávio e Carlos Bolsonaro". Em ação político-partidária, esses projetos deram origem a aproximadamente 200 projetos de lei, aprovando 46 leis similares. Conforme os autores:

\begin{abstract}
O primeiro palco de encenação se deu entre 2013 e 2014, fase final de tramitação do Plano Nacional de Educação - PNE (Lei n. 13.005, de 25 de junho de 2014). Ali, entre outras polêmicas igualmente importantes, embora menos ruidosas, reacionários e fundamentalistas lograram emplacar uma falácia jurídica: a redação final do PNE teria excluído a abordagem de gênero e diversidade sexual, uma vez que a diretriz sobre a "erradicação de todas as formas de discriminação" não contemplara, por veto político desses grupos e omissão da maioria parlamentar, emendas que buscavam afirmar expressamente aquelas dimensões de desigualdades a serem combatidas.
\end{abstract}

Dessa forma, "[...] as decisões do STF reforçam a ideia de que as escolhas pedagógicas são parte do exercício regular da condição docente, sendo inclusive parte de sua liberdade fundamental de expressão na profissão".

A desconstrução de Paulo Freire via movimento EsP encontra forte amparo no ensaísta e influenciador digital Olavo de Carvalho. Em seu blog é possível localizar uma profusão de textos que contém ataques a Paulo Freire reproduzidos também na página eletrônica ${ }^{7}$ do EsP: “Vocês conhecem alguém que tenha sido alfabetizado pelo método Paulo Freire? Alguma dessas raras criaturas, se é que existem, chegou a demonstrar competência em qualquer área de atividade técnica, científica, artística ou humanística?" (CARVALHO, 2012, s/p). Em outro excerto, Carvalho (2012, s/p) reforça:

\footnotetext{
Não digo isso para criticar a nomeação póstuma desse personagem como "Patrono da Educação Nacional". Ao contrário: aprovo e aplaudo calorosamente a medida. Ninguém melhor que Paulo Freire pode representar o espírito da educação petista, que deu aos nossos estudantes os últimos lugares nos testes internacionais, tirou nossas universidades da lista das melhores do mundo e reduziu para um tiquinho de nada o número de citações de trabalhos acadêmicos brasileiros em revistas científicas internacionais.
}

Miguel Nagib, fundador do EsP considera que "Ninguém contribuiu tanto para transformar as escolas em centros de doutrinação ideológica" ${ }^{\prime 8}$. As críticas de Carvalho ${ }^{9}$ (1999, s/p) a Freire remontam à década de 1990: 
Paulo Freire é um sujeito oco, o tipo acabado do pseudo-intelectual militante. Sua fama baseia-se inteiramente no lucro político que os comunistas obtêm do seu método. Esse método, aliás, não passa de uma coleção de truques para reduzir a educação à doutrinação sectária. Um dia teremos vergonha de ter dado atenção a essa porcaria.

Para Penna (2016), o EsP recorre ao uso de terminologias que objetivam deturpar a concepção original, com vistas a desqualificar seu uso. Para exemplificar, o autor destaca um primeiro elemento caracterizado pelo uso de expressões sem definição precisa "de maneira que uma ampla gama de casos possa ser enquadrada usando essas expressões. Cito, como exemplo, os termos: "doutrinação ideológica", "ideologia de gênero" e "marxismo cultural" (PENNA, 2016, p. 94).

Soma-se esta estratégia à desqualificação direta de professores que se opõem ao projeto do EsP, considerando que esse processo "não se dá por meio de uma argumentação racional, mas através de ataques pessoais e imagens que representam o professor, a escola e seus pensadores", sendo comum, neste processo, validar os docentes "como ameaças à crianças inocentes, citando casos particulares considerados assustadores e insinuando que uma parcela significativa dos professores age da mesma maneira". Não importa para a argumentação qualquer sentido de racionalidade como, por exemplo, a busca de "dado estatístico para apoiar essa generalização indevida". Reforça-se a todo momento a ideia de uma "ameaça abstrata que coloca em suspeição todos os professores e todo o sistema escolar" (PENNA, 2016, p. 95).

A composição dos membros do EsP localiza no seu interior pessoas ligadas à autodenominada "nova direita brasileira", com formação majoritária na área jurídica e sem vínculos com o campo educacional. Embora exista uma base de conhecimento jurídico no interior do grupo, os projetos de lei propostos são eivados de contradições. O Projeto de Lei n. 867/2015 de autoria do deputado federal Izalci (PSDB/DF), similar a outros em diferentes entes federados, estabelece que "a educação nacional respeitará o princípio da 'neutralidade política, ideológica e religiosa do Estado'" (VASCONCELOS, 2016, p. 79).

O mesmo projeto de lei afirma como direito dos pais "que seus filhos recebam a educação moral que esteja de acordo com suas próprias convicções" (VASCONCELOS, 2016, p. 80). Esta proposta claramente não conhece a realidade diversa das escolas públicas. Vasconcelos (2016, p. 80) questiona, “O que ocorreria, por exemplo, em uma sala de aula com alunos de famílias evangélicas, umbandistas, católicas, espíritas, judias, islâmicas, candomblecistas e ateias?". Evidente que o professor não poderia abordar a diversidade religiosa de acordo com os diversos interesses das famílias.

O mais grave desse projeto é desconsiderar o pressuposto intrínseco à democracia escolar, ou seja, a necessidade de a escola tratar os temas de forma diversa e não reproduzir particularismos familiares no espaço da sala de aula. O professor que, de alguma forma, contrariar esses particularismos passa a ser criminalizado, posto que o projeto interdita o debate de alguns temas como, por exemplo, "a religiosidade afro-brasileira, sobre diversidade de gêneros ou sobre pensamento marxista" (VASCONCELOS, 2016, p. 81). 
O autor destaca, ainda, que "a proposta de criminalização por 'assédio ideológico' ou 'doutrinação marxista' é muito semelhante ao que as ditaduras do Cone Sul chamaram de 'terrorismo intelectual'”. Estas proposições se assemelham aos momentos mais sombrios de nossa história, em que ditaturas instaladas nos países latino-americanos nas décadas de 1960 e 1970 prenderam e torturaram pessoas por divulgar as ideias de Paulo Freire.

\begin{abstract}
[...] trata-se de uma tentativa de disfarçar a incompatibilidade de uma escola tecnocrática e conservadora com aquilo que Paulo Freire definiu como "educação como prática da liberdade". Com isso, pretendem fortalecer o viés autoritário da instituição escolar e blindar os jovens do contato com o contraditório, isto é, com a teoria social crítica e com o respeito à diversidade (VASCONCELOS, 2016, p. 81).
\end{abstract}

Ximenes (2016) apresenta uma série de argumentos para reforçar o caráter ilegal das proposições do EsP referentes à educação, a começar por essa questão da neutralidade da escola. Segundo o autor,

[...] 'neutralidade' não é um valor constitucional, já que é incompatível com a própria definição de Estado Democrático de Direito, que tem no estabelecimento de objetivos políticos, como "construir uma sociedade livre, justa e solidária" e "promover o bem de todos, sem preconceitos de origem, raça, sexo, cor, idade e quaisquer outras formas de discriminação" (Constituição, art. $3^{\circ}$ ), o eixo central de sua própria justificação (XIMENES, 2016, p. 52).

Mesmo a educação escolar não pode ser neutra, posto que um conjunto de normativos de âmbito global, determinam o contrário:

[...] Art. 26, parágrafo 2º, da Declaração Universal dos Direitos Humanos; art. 5o, 'a', da Convenção relativa à Luta contra a Discriminação no Campo do Ensino; art. 13 do Pacto Internacional de Direitos Econômicos, Sociais e Culturais; art. $7^{\circ}$ da Convenção contra a Discriminação Racial; art. $1^{\circ}$ da Convenção sobre os Direitos da Mulher e art. 29, parágrafo 1ํㅡㄹ da Convenção sobre os Direitos da Criança, considerando-se apenas os documentos normativos de âmbito global (XIMENES, 2016, p. 53).

Pode-se concluir, portanto, que o EsP tem como objetivo limitar a educação a alguns parâmetros privados, definidos pelas famílias. Evita-se, assim, o convívio com a diversidade e com a contradição, tendo como instrumento a criminalização do professor e a definição das temáticas vetadas no ambiente escolar, dentro do princípio de conceitos amplos e vagos que caracterizam o movimento. Vasconcelos (2016, p. 82)) assevera que em "um país culturalmente diversificado e politicamente efervescente como o Brasil, podemos ter certeza de que a tarefa deles não será fácil".

Feita essa contextualização do Escola sem Partido, acompanhada de uma análise crítica dos pressupostos que fundamentam as atividades deste movimento, passamos na sequência à uma discussão dos princípios de uma educação de acordo com Paulo Freire. 


\section{O significado em Freire da não neutralidade da educação}

Ao analisar o cerne das críticas a Paulo Freire, constata-se que elas se centram na acusação de não neutralidade, de sua filiação a uma ideologia, notadamente de esquerda. Ao lado das questões de fundo moral e religioso, o combate ao componente político da educação é um dos elementos que constituem um dos pontos centrais da atuação do EsP, denominados por eles, em suas definições genéricas e imprecisas como "doutrinação" ou "marxismo cultural".

Para problematizar esse tema, parte-se do conceito de ideologia, pois este contribui para a reflexão sobre os fundamentos da prática educacional. Sem a pretensão de aprofundar esse debate, conceituamos o que é ideologia e como esta se articula à prática educacional. Chauí (2016, p. 245) argumenta que "A noção de ideologia pode ser compreendida como um corpus de representações e de normas que fixam e prescrevem de antemão o que se deve e como se deve pensar, agir e sentir". A definição insere-se em uma análise mais ampla da sociedade de classes, em que a ideologia legitima a divisão social.

[...] a universalização do particular, a interiorização do imaginário como algo coletivo e comum e a coerência da lógica lacunar fazem com que a ideologia seja uma lógica da dissimulação (da existência de classes sociais contraditórias) e uma lógica da ocultação (da gênese da divisão social) (CHAUÍ, 2016, p. 245).

Durante uma entrevista, ao ser questionado sobre a relação entre a educação e a política, Freire ressaltou que a formulação de educação como um ato político foi elaborada ao longo do tempo. O próprio Freire informa que essa construção se deu em três momentos distintos. O primeiro consta no livro Educação como Prática da Liberdade, onde o autor explicita: "não há um momento sequer que eu me refira à politicidade da Educação. Não há um momento sequer" (FREIRE; BETTO, 1986, p. 17). Um segundo momento relatado por Freire "no começo do exílio, no Chile, eu comecei a falar de um aspecto político da educação ou do aspecto político da educação". Por fim, em sua formulação acabada, tem-se o terceiro momento narrado pelo autor:

O terceiro momento, que assumo na Europa, no exílio, é aquele em que digo: "Não, não há um aspecto político; a educação é política". Ela tem uma politicidade, a política tem uma educabilidade, que dizer: há uma natureza política do ato educativo, indiscutível (FREIRE; BETTO, 1986, p. 17- 18).

Essa é uma questão inescapável, cabe aos educadores compreendê-la e explicitá-la, "não é demais repetir aqui essa afirmação, ainda recusada por muita gente, apesar de sua obviedade, a educação é um ato político". Portanto, se todo docente tem sua política, a sua não neutralidade exige "que se assuma como política, e viva coerentemente sua opção 
progressista, democrática ou autoritária, reacionária, passadista ou também espontaneísta" (FREIRE, 1994, p. 85).

Importante salientar que o próprio Freire respondeu em várias oportunidades sobre a necessidade de uma educação radicalmente democrática, incompatível com a imposição de opiniões, seja dos grupos reacionários detentores do poder, seja de grupos progressistas que os combatem. O autor afirma que práticas substantivamente democráticas são inconciliáveis com "as atitudes e as práticas elitistamente autoritárias de quem, julgando-se dono da verdade revolucionária, transforma as classes populares em mera incidência de suas palavras de ordem" (FREIRE; BETTO, 1986, p. 64).

Ou seja, em Freire não existe a possibilidade da neutralidade no ato educativo, que sempre carrega em si os posicionamentos implícitos ou explícitos daqueles que formulam e praticam o ensino e a aprendizagem; por outro lado, isso não significa que a escola deva ser um espaço de "doutrinação", como alegam os membros da EsP. A radicalidade democrática em Freire impede explicitar esse posicionamento. A escola realmente democrática não pode ser espaço de imposição de saberes ou espaço de interjeição de saberes; todos os saberes são importantes e, por isso mesmo, não devem ser ignorados.

Se o EsP se caracteriza pela interdição de alguns temas e imposição de outros para o ambiente escolar, a democracia em Freire tem na tolerância uma chave para a compreensão. Um educador democrático se caracteriza pelo respeito à diferença, esse professor "tem que respeitar e tolerar inclusive a postura politicamente oposta à sua, e testemunhar aos educandos a sua capacidade de conviver com essas diferenças". Concluí Freire e Guimarães (1984, p. 88) que "quanto mais crítico e lúcido é o educador, numa posição radicalmente democrática, tanto mais ele testemunha a sua tolerância".

A centralidade do respeito à pessoa, o respeito pelo outro é o que diferencia os posicionamentos de Paulo Freire dos posicionamentos da EsP. Freire (1996, p.36) argumenta "Primordialmente, minha posição tem de ser a de respeito à pessoa que queira mudar ou que recuse mudar. Não posso negar-lhe ou esconder-lhe minha postura, mas não posso desconhecer o seu direito de rejeitá-la".

Ressalta, entretanto, que isso não se confunde com a ideia de neutralidade, pois "Em nome do respeito que devo aos alunos não tenho por que me omitir, por que ocultar a minha opção política, assumindo uma neutralidade que não existe". Por fim, destaca que o professor omitir seus posicionamentos é uma forma de desrespeitar o aluno, tirando dele a possibilidade de compreender; pode-se mesmo acrescentar a possibilidade de pensar e formular seu próprio posicionamento. Finaliza o autor, sobre a pretensa neutralidade do professor: "O meu papel, ao contrário, é o de quem testemunha o direito de comparar, de escolher, de romper, de decidir e estimular a assunção deste direito por parte dos educandos" (FREIRE, 1996, p.36).

A análise da extensa obra de Freire revela sua total concordância com a ideia de que práticas de doutrinação não devem fazer parte da educação, segundo ele: “O que me 
parece horrível [...] é a militância sectária, realmente intolerante, que não é radical, que ultrapassa a radicalidade e cai no terreno do sectarismo. É esse tipo que pretende fazer a cabeça dos outros" (FREIRE; GUIMARÃES, 1984, p. 88).

Corroborando esse entendimento, Chauí (2016) considera a ideia de conscientização como um discurso presente no meio educacional e que, em alguma medida, pode, ele mesmo, ser carregado de uma carga ideológica:

Qual seria, então, o risco ideológico da noção de conscientização? Em primeiro lugar, haveria o risco de imaginar o aluno (e a classe social) como uma consciência latente ou virtual, adormecida no seu ser em si e que o professor (ou a vanguarda) viria atualizar ou despertar. Há o risco da atitude iluminista. Em segundo lugar, haveria o risco de imaginar o aluno (e a classe social) como uma consciência de si que, por ignorar-se a si mesma, isto é, não ser ainda para si, tenderia a manifestar-se através de palavras e de ações alienadas ou como "falsa consciência". Assim sendo, parecerá necessário esperar que a desalienação ou a consciência "verdadeira" lhe seja trazida de fora por aqueles que "sabem". Há o risco ideológico de diferenciar o aluno (e a classe social) do professor (e da vanguarda) em termos de imaturidade/ maturidade, ignorância/saber, alienação/verdade, em suma, diferenciar hierarquizando e fazendo com que um dos polos seja uma espécie de receptáculo vazio e dócil no qual venha depositar-se um conteúdo exterior trazido pelo outro polo. Com isso, sob o nome de conscientização, reedita-se sob nova roupagem o conservadorismo e o autoritarismo da educação que se pretendia combater (CHAUí, 2016, p. 255).

Do ponto de vista conceitual, é necessário aprofundar a questão da neutralidade na educação, pois existe uma acusação explícita de que Paulo Freire não tem uma proposta neutra sobre a educação.

Sobre esse aspecto seria pertinente analisar duas questões, a primeira sobre a neutralidade no Movimento EsP e a segunda sobre a ideia de uma educação baseada na neutralidade. Para Frigotto (2016, p. 12), o Escola sem Partido está longe de ser neutro e apartidário, pelo contrário, trata-se:

[...] da escola do partido absoluto e único: partido da intolerância com as diferentes ou antagônicas visões de mundo, de conhecimento, de educação, de justiça, de liberdade; partido, portanto da xenofobia nas suas diferentes facetas: de gênero, de etnia, da pobreza e dos pobres etc.

Oliveira, Storto e Lanza (2019) destacam a proximidade desses grupos a correntes político ideológicas de direita, que divulgam plataformas de combate ao comunismo e grupos de esquerda. Entretanto, os temas combatidos pelo EsP vão além do combate ao comunismo, vetando vários temas pontuais, como "[...] política contemporânea, diversidade religiosa, educação sexual e estudos de gênero, direitos humanos, cultura e história afro-brasileira, ditadura militar brasileira (1964-1985), entre outros"' (OLIVEIRA; STORTO; LANZA, 2019, p. 475). 
Este entendimento joga por terra um dos principais argumentos utilizados pela EsP para o combate à Paulo Freire, que reside exatamente na falta de neutralidade de sua proposta educacional.

É fato que Paulo Freire não defende uma educação neutra, ao contrário “O ato de estudar, tal como o ato de ensinar e de aprender, é concebido por Paulo Freire como um ato cultural e ético-político, muito mais do que como, simplesmente, um ato estritamente escolar, didático" (LIMA, 2016, p. 147). Para Freire, a educação tem como objetivo possibilitar aos indivíduos o "ser mais", o "saber mais", considerando que tanto alunos como professores são seres inconclusos, em processo permanente de desenvolvimento.

Portanto, é necessário problematizar os conceitos de neutralidade que embasam a ação educacional na perspectiva do EsP, uma vez que em uma análise mais acurada pode-se afirmar que não existe ação de neutralidade, seja no campo da ação educativa, seja no campo da ação política mais ampla. Parte-se, portanto, de Freire para discutir a temática.

Para Freire o debate de ideias é um pressuposto da atividade educativa e não pode ser interditado. O autor salienta: "Posso não aceitar a concepção pedagógica deste ou daquele autor e devo inclusive expor aos alunos as razões por que me oponho a ela mas, o que não posso, na minha crítica, é mentir. É dizer inverdades em torno deles" (FREIRE, 1996, p. 18).

De forma mais específica, Freire (1996) critica a pretensa neutralidade das práticas educativas qualificadas por ele como um discurso reacionário, contrário à compreensão do próprio mundo. Assim, “o espaço pedagógico, neutro por excelência, é aquele em que se treinam os alunos para práticas apolíticas, como se a maneira humana de estar no mundo fosse ou pudesse ser uma maneira neutra" (FREIRE, 1996, p. 110). Freire defende uma postura ética do docente, que não deve impor sua vontade, não deve proferir inverdades, porém não deve, igualmente, ser neutro, tem que se posicionar, e mais que isso tem que expor aos alunos as razões que motivam seus posicionamentos.

Em outras obras Paulo Freire (1992) retoma o tema; em "Pedagogia da Esperança: um reencontro com a Pedagogia do Oprimido", manifesta-se contra a imposição da leitura de mundo dos professores aos estudantes, ao mesmo tempo em que desmascara a ideologia da neutralidade:

O que não é possível na prática democrática, é que o professor ou a professora [...] imponha aos alunos sua 'leitura de mundo', em cujo marco situa o ensino do conteúdo. Combater o autoritarismo de direita ou de esquerda não me leva, contudo, à impossível neutralidade, que não é outra coisa senão a maneira manhosa com que se procura esconder a opção.

Em síntese, o discurso da neutralidade é na verdade uma forma de esconder determinadas opções teórico-metodológicas ou opções políticas no sentido amplo do termo. Ao docente, carregado de ética, cabe explicitar suas posições, sendo assim ético com seus alunos e com sua prática, o que não pode ser conseguido ao ocultar suas opções e as motivações em adotá-las. Parece evidente que este é o caso do EsP, posto que propagam a neutralidade para ocultar suas opções teóricas, metodológicas e políticas. 


\title{
Paulo Freire como alvo preferencial do Escola sem Partido
}

Comecemos este item esclarecendo a razão principal pela qual Paulo Freire foi escolhido como um alvo preferencial do movimento Escola Sem Partido. A razão é que a pedagogia de Paulo Freire está comprometida radicalmente com a democratização substantiva da realidade brasileira.

Consiste, portanto, na alternativa pedagógica que melhor expressa, em termos educacionais, a luta pela democratização substantiva e é exatamente à democratização substantiva que o movimento Escola Sem Partido se opõe centralmente. A oposição à democratização substantiva é, no fundo, a própria razão de ser do movimento Escola sem Partido.

Definimos democratização substantiva a partir das contribuições de Marilena Chauí e do próprio Freire. Para Chauí (2019) ${ }^{10}$, a concepção de direito é central na democracia. A autora enfatiza que nas sociedades democráticas o direito não é sinônimo de necessidade, de carência ou mesmo de interesses particulares:

\begin{abstract}
Mas se distingue fundamentalmente do privilégio, que é sempre particular. Os privilégios se opõem aos direitos. A democracia não pode se confinar a um setor específico. Ela determina a forma das relações sociais e de todas as instituições, ela é o único regime político que é a forma social da sociedade coletiva. Uma sociedade não é um simples regime de governo porque há eleições, respeito à vontade da maioria e das minorias. A democracia é uma criação social de tal maneira que determina, dirige e controla o poder dos governantes. Do ponto de vista político, todos os cidadãos têm competência para opinar e decidir. A política não é uma questão técnica nem científica, mas é a ação coletiva, a decisão coletiva quanto aos interesses da própria sociedade (CHAUÍ, 2019, s/p).
\end{abstract}

A presença do contraditório é inerente às sociedades que adotam regimes democráticos. Na perspectiva de Chauí:

[...] a democracia é uma forma sociopolítica definida pelo princípio da isonomia (igualdade dos cidadãos perante a lei) e da isegoria (direito de todos para expor em público suas opiniões, vê-las discutidas, aceitas ou recusadas em público), tendo como base a afirmação de que todos são iguais porque livres, isto é, ninguém está sob o poder de um outro porque todos obedecem às mesmas leis das quais todos são autores (autores diretamente, numa democracia participativa; indiretamente, numa democracia representativa) (CHAUÍ, 2020, p. 1).

Chauí (2020, p. 2) identifica os regimes democráticos como "[...] única forma sociopolítica na qual o caráter popular do poder e das lutas tende a evidenciar-se nas sociedades de classes, na medida em que os direitos só ampliam seu alcance ou só surgem como novos pela ação das classes populares contra a cristalização jurídico-política que favorece a classe dominante". 


\begin{abstract}
Por conseguinte, é a única forma sociopolítica na qual, ao contrário de todas as outras, o conflito é considerado legítimo e necessário, buscando mediações institucionais para que possa exprimir-se. A democracia não é o regime do consenso, mas do trabalho sociopolítico do dissenso. Politicamente, graças à prática da criação de direitos, a democracia surge como o único regime político realmente aberto às mudanças temporais, uma vez que faz surgir o novo como parte de sua existência e, consequentemente, a temporalidade como constitutiva de seu modo de ser, de maneira que a democracia é a sociedade verdadeiramente histórica, isto é, aberta ao tempo, ao possível, às transformações e ao novo (CHAUÍ, 2020, p. 2).
\end{abstract}

Percorrem a sociedade brasileira marcas históricas próprias de uma estrutura antidemocrática, ancorada em elementos como violência e autoritarismo. Embora se configure como democrático, o projeto societário brasileiro aceita fortemente o princípio da isonomia, mas não o de isegoria, notadamente por esse princípio traduzir o "direito de todos para expor em público suas opiniões, vê-las discutidas, aceitas ou recusadas em público" (CHAUÍ, 2020, p. 2).

A concepção de democracia é central na produção freireana. Na obra "Educação como prática de liberdade" (1967/1977) esse termo é citado 43 vezes. Na acepção de Freire:

A democracia que, antes de ser forma política, é forma de vida, se caracteriza sobretudo por forte dose de transitividade de consciência no comportamento do homem. Transitividade que não nasce e nem se desenvolve a não ser dentro de certas condições em que o homem seja lançado ao debate, ao exame de seus problemas e dos problemas comuns. Em que o homem participe (FREIRE, 1967/1977, p. 81).

A democracia, portanto, opera com o diálogo e com a participação. Assim, "Falar, por exemplo, em democracia e silenciar o povo é uma farsa. Falar em humanismo e negar os homens é uma mentira" (FREIRE, 1968/1983, p. 52). Freire (1967/1977) desvela que o uso que os setores conservadores fazem da democracia descaracteriza o sujeito e sua participação na sociedade. Desvela, também, a deturpação da própria democracia, criando-se um simulacro da realidade, caracterizada por "formas de vida 'mudas', quietas e discursivas, das fases rígidas e militarmente autoritárias".

Para compreender a razão pela qual Paulo Freire foi escolhido como um alvo preferencial pelo movimento Escola Sem Partido é importante recuperar o que aconteceu em relação a Paulo Freire em outro momento em que os setores populares avançavam, começo da década de 1960, avanço que é interrompido violentamente pelo golpe de 1964.

Toledo (2004, p. 15) ressalta a abrangência do golpe de 1964, que, para além do ataque direto à democracia, alvejou intensamente outras esferas, constituindo-se em ação "[...] contra as reformas sociais e políticas; uma ação repressiva contra a politização das organizações dos trabalhadores (no campo e nas cidades); um estancamento do amplo e rico debate ideológico e cultural que estava em curso no país".

O golpe estancou um rico e amplo debate político, ideológico e cultural que se processava em órgãos governamentais, partidos políticos, associações de classe, 
entidades culturais, revistas especializadas (ou não), jornais etc. Assim, nos anos 60, conservadores, liberais, nacionalistas, socialistas e comunistas formulavam publicamente suas propostas e se mobilizavam politicamente em defesa de seus projetos sociais e econômicos. Mas, o golpe também visou estancar a democracia que se expressava pela demanda da ampliação da cidadania dos trabalhadores urbanos e rurais (TOLEDO, 2004, p. 18 - 19).

Para Fernandes (1980, p. 113), “O que se procurava impedir era a transição de uma democracia restrita para uma democracia de participação ampliada [...]".

Paulo Freire foi um dos primeiros brasileiros punidos pelo regime autoritário. $\mathrm{O}$ "Programa Nacional de Alfabetização", instituído por meio do Decreto nº 53.465 de 21 de janeiro de 1964 e que deveria empregar o "Sistema Paulo Freire para alfabetização em tempo rápido", foi extinto pelo 'novo' regime, logo após o golpe de Estado em 1 de abril de 1964. Mas, de fato o "Programa Nacional de Alfabetização" foi um dos elementos mais importantes que levaram os setores golpistas a organizarem o golpe.

Se a participação das massas alfabetizadas já alterava substancialmente o quadro das relações de poder, que ocorreria se fosse permitida a participação do conjunto das classes populares? Para os grupos da direita, isto parecia significar o fim da democracia. Em verdade, poderia significar o começo de uma verdadeira democracia para o povo e o fim da história política de muitos dos setores privilegiados (FREIRE, 1977, p. 54).

A interrupção e a consequente anulação de projetos de alfabetização popular foram práticas discricionárias da ditadura civil-militar. A esse respeito, Haddad e Di Pierro (2000, p. 113), ressaltam que "O golpe militar de 1964 produziu uma ruptura política em função da qual os movimentos de educação e cultura populares foram reprimidos, seus dirigentes, perseguidos, seus ideais, censurados".

A repressão foi a resposta do Estado autoritário à atuação daqueles programas de educação de adultos cujas ações de natureza política contrariavam os interesses impostos pelo golpe militar. A ruptura política ocorrida com o movimento de 64 tentou acabar com as práticas educativas que auxiliavam na explicitação dos interesses populares. O Estado exercia sua função de coerção, com fins de garantir a "normalização" das relações sociais (HADDAD; DI PIERRO, 2000, p. 113).

A análise de Freire sobre o analfabetismo marca uma diferença substantiva em relação ao regime autoritário:

Para a concepção crítica, o analfabetismo nem é uma "chaga", nem uma "erva daninha" a ser erradicada, nem tampouco uma enfermidade, mas uma das expressões concretas de uma realidade social injusta. Não é um problema estritamente linguístico nem exclusivamente pedagógico, metodológico, mas político, como a alfabetização por meio da qual se pretende superá-lo. Proclamar sua neutralidade, ingênua ou astutamente, não afeta em nada a sua politicidade intrínseca (FREIRE, 1982, p. 15-16). 
Para Teixeira (2012, p. 1), o regime militar operou notadamente como "força repressiva contra uma das mais ricas, fecundas e criativas experiências de alfabetização de adultos do país". A ação preferencial centra-se na extinção da política de educação popular originária do Governo Goulart (1961 - 1964). O autor indica que:

[...] organizada na época pelo educador Paulo Freire por meio do Plano Nacional de Alfabetização (PNA); as ações repressivas contra o Movimento de Cultura Popular (MCP) de Recife em Pernambuco e a Campanha de Pé no Chão também se aprende a Ler em Natal no Rio Grande do Norte; a intervenção sofrida pelo Movimento de Educação de Base (MEB) ligado à Igreja Católica; e a perseguição aos Centros Populares de Cultura (CPC's) da União Nacional dos Estudantes (UNE), bem como à própria entidade (TEIXEIRA, 2012, p. 1).

A emergência de políticas de alfabetização de jovens e adultos, nas décadas de 1950 e 1960, estão intrinsicamente ligadas a dois fatores: a) elevada quantidade de analfabetos que, conforme Teixeira (2012, p. 2), "Nos anos 1960 o IBGE calculava um índice de 40\% de analfabetos entre a população com mais de 15 anos, isso representava cerca de 16 milhões de pessoas", e, b) a restrição do voto para os analfabetos, "A Constituição de 1946 proibia o analfabeto de votar, o resultado era que boa parte dos brasileiros estavam impedidos de participar do processo político" (TEIXEIRA, 2012, p. 2). Nesse contexto,

A alfabetização popular passou a ser entendida como um instrumento da luta política, aliada a uma nova ideia de cultura popular, que passava de uma popularização da cultura erudita para uma valorização da cultura do próprio povo e a construção de elementos culturais novos. Esses elementos somados ao contexto de crise econômica e política do período propiciaram o início de uma postura ativa das camadas populares, na exigência de seus direitos e na transformação de sua realidade social. A formação de um universo mais amplo de eleitores aumentava a possibilidade de mudanças reais no quadro político. Foi nesse contexto que surgiram diversos movimentos e iniciativas voltadas para a alfabetização de adultos (TEIXEIRA, 2012, p. 2-3).

Depreende-se que a associação da educação de jovens e adultos como "instrumento da luta política" tornou tanto os programas e projetos como os seus idealizadores e participantes "inimigos" do regime militar. Assim, "Logo após o golpe, durante a chamada Operação Limpeza, foram muitos os militantes e coordenadores presos. Professoras, monitores e funcionários também sofreram com as perseguições da ditadura". O autor reforça que "O combate feito pela ditadura àqueles que combatiam o analfabetismo foi implacável" (TEIXEIRA, 2012, p. 5).

Em âmbito nacional, o Plano Nacional de Alfabetização (PNA) não foi implementado, ficando restrito à etapa de planejamento. Esse fato indica que se constitui em plataforma de governo tanto no período da ditadura civil-militar, quanto no tempo presente, extirpar Paulo Freire da educação nacional. No contexto do golpe de 1964, dois dispositivos sustentaram essa ação. A Portaria n. 237, de 14 de abril de 1964, que asseverava: “Considerando 
que tais atividades têm base em ideologia contrária ao Regime Democrático e estão, no seu conjunto, subordinadas a planos" (BRASIL, 1964a); e o Decreto n 53.886 de 14 de abril de 1964, anulando o teor do Decreto n. 53.465, de 21 de janeiro de 1964, portanto extinguia o Programa Nacional de Alfabetização do Ministério da Educação e Cultura:

Art. $1^{0}$ Fica revogado o Decreto nº 53.465, de 21 de janeiro de 1964, que instituiu o Programa Nacional de Alfabetização do Ministério da Educação e Cultura.

Art. $2^{\circ} \mathrm{O}$ Departamento Nacional de Educação recolherá todo o acervo empregado na execução do Programa Nacional de Alfabetização, cujos recursos também ficarão à disposição daquele órgão.

Um aspecto que merece atenção é a justificativa para a extinção do PNA, pois no texto normativo lançam mão da democracia, interditada com o "novo regime", para anunciar a necessidade de eliminar o analfabetismo e "veicular ideias nitidamente democráticas e preservar as instituições e tradições de nosso povo".

CONSIDERANDO a necessidade de reestruturar o Planejamento para a eliminação do analfabetismo no país;

CONSIDERANDO ainda que o material a ser empregado na Alfabetização da População Nacional deverá veicular idéias nitidamente democráticas e preservar as instituições e tradições de nosso povo (BRASIL, 1964b).

No campo educacional interessava ao governo autoritário descontinuar as políticas públicas gestadas no Governo João Goulart. Nesse contexto, Paulo Freire passa a ser visto como perigoso.

Ao final da solenidade, o general Castello Branco comentou com Calazans Fernandes que o trabalho realizado em Angicos o preocupava, pois serviria "para engordar cascavéis nesses sertões". No jantar oferecido naquela noite de 1963, o general disse a Paulo que já havia sido alertado sobre o seu caráter subversivo - e que agora estava convencido disso por sua defesa de uma "pedagogia sem hierarquia". A manifestação do general, que foi empossado na presidência com o golpe militar, explica a rapidez com que Paulo seria preso já no ano seguinte, em meio à implantação do Programa Nacional de Alfabetização (HADDAD, 2019, p. 67).

Uma análise mais acurada permite afirmar que para além do ataque direto aos programas e políticas de alfabetização de jovens e adultos e ao próprio Paulo Freire, os militares tentavam eliminar qualquer pensamento dissonante: "[...] para os novos mandatários do poder, alfabetização não deveria ter relação com a política e muito menos quando coordenada por grupos e políticos de esquerda" (TEIXEIRA, 2012, p. 10).

Teixeira (2012, p. 9-10) reforça essa perspectiva “Numa época em que o debate político estava suspenso para as classes populares, um método de alfabetização baseado justamente na discussão política, não se encaixava no modelo educacional preconizado pelo regime militar. 
Esclarecido que o golpe de 64 foi em grande medida um golpe contra Paulo Freire, vejamos que, de certa forma, isso se repete com a escolha de Paulo Freire como alvo preferencial pelo movimento Escola Sem Partido.

Também vivíamos, como no início da década de 1960, um avanço substancial das forças populares em direção à democratização substantiva da sociedade brasileira e, como em 1964, os setores privilegiados se organizaram para o golpe.

O central é que a proposta freireana é a alternativa pedagógica que melhor expressa em termos educacionais a luta pela democratização substantiva que os setores privilegiados não aceitam.

Y es fundamental intentar entender, no exentos de perplejidad, el nacimiento del discurso de odio visceral que se ha ceñido sobre Freire en el Brasil antes de la asunción y en estos primeros tiempos del gobierno de Jair Bolsonaro. Todos hemos visto con asombro y dolor aquellas pancartas con el slogan: Basta de Paulo Freire. También nos ha causado una inmensa pena la sola idea de quitarle su título de Patrono de la Educación brasileña. Sin duda alguna nos ha generado repulsión y congoja la incitación al odio personalizada en su figura, ni más ni menos que la figura de un educador, de un educador cuyos ecos políticos y educativos no cesan en el presente y que deberían estar a resguardo de cualquier estigmatización provocadora o de toda sospecha vilmente agrietada (SKLIAR, 2020, p. 20).

\section{Considerações finais}

Procurou-se, neste texto, destacar por que, no contexto atual brasileiro, o movimento EsP elegeu Paulo Freire como um dos alvos preferenciais, procurando analisar alguns fundamentos que embasam essas práticas, com paralelos à perseguição a Freire no período da ditadura civil-militar no período de 1964-1985.

É certo que a perseguição a Paulo Freire em diferentes momentos históricos tem uma base autoritária, uma ideia de controle sobre o diferente, o considerado subversivo. A esse respeito, Freire (1986) afirma sobre os governos iniciados em 1964: "Sempre digo que o regime militar, que se implantou entre nós a serviço do sistema capitalista, não inventou o autoritarismo. É indiscutível, porém, que deu à tradição autoritária que nos marca uma excepcional contribuição" (FREIRE; BETTO, 1986, p. 63-64).

Sob a acusação de uma educação sem neutralidade, uma educação carregada de sentidos políticos, Freire foi e ainda é atacado, mais pelo que representa do que pela sua real influência nos processos educacionais do tempo presente.

Portanto, a partir do que foi explanado, cabe uma síntese sobre o que representa a figura e as ideias de Paulo Freire, considerando que as acusações que recebe são realmente o elemento central de seu pensamento. O diálogo no ato educativo é central no pensamento freireano, a educação é política e como tal nunca é neutra. Todo ato educativo vem carregado de sentidos, cabendo ao educador explicitar suas opções por meio do diálogo e do respeito à diversidade de opiniões na sociedade. Freire salienta que o diálogo se dá 
entre iguais, entre saberes não hierarquizados. Portanto, não existem saberes melhores que outros, saberes mais válidos que outros, há saberes diferentes sobre o mundo.

Opções autoritárias que visam impor determinada concepção de sociedade, opções que visam interditar determinados temas nas práticas educativas são incompatíveis com a perspectiva freireana, na medida em que a educação em Freire é essencialmente democrática, é baseada no diálogo, é a busca da realização da potencialidade do ser humano, o "ser mais".

Recebido em 29/07/2020. Aprovado em 10/08/2020.

\section{Notas}

1 Em 2020, o STF julgou como inconstitucionais ao menos três leis municipais que se baseavam nos princípios do EsP. Trata-se de Arguição de Descumprimento de Preceito Fundamental (ADPF). Em 8 de maio, decidiu sobre a ADPF n. 526, que versava sobre legislação antigênero do município de Foz do Iguaçu (PR). No dia 28 de maio julgou a ADPF n. 467 que tratou da legislação de Ipatinga (MG), que excluía da política municipal de educação quaisquer referências à diversidade de gênero e orientação sexual, já havia decidido sobre ADPF n. 457, reconhecendo a inconstitucionalidade de lei de conteúdo similar do município de Novo Gama (GO).

2 Ver: http://www.escolasempartido.org/quem-somos/

3 Fundadora do PSDB, exerceu o cargo de secretária municipal da Educação de São Paulo, entre 1982 a 1985, durante o governo de Mário Covas e o mandato de deputada estadual de São Paulo pelo PMDB entre 1987 a 1991.

4 Ver: http://www.escolasempartido.org/quem-somos/

5 Dados de Controle do e-Cidadania indica como data da publicação da Ideia o dia 15/09/2017 e como data de alcance dos apoios necessários o dia 30/09/2017, na qual se registrou um total de apoios de 20.566 apoiadores. Os dados foram coletados por meio da página específica da ideia: http://www12.senado.leg.br/ecidadania/ visualizacaoideia $\mathrm{id}=90310$

6 Nos termos do parágrafo único do art. 6º da Resolução do Senado Federal no 19 , de 2015, combinado com o art. 102-E do Regimento Interno do Senado Federal (RISF), compete à CDH opinar sobre as Ideias Legislativas registradas no Programa e-Cidadania, que alcançarem um total de 20 mil apoios em um prazo de 4 (quatro) meses após seu registro, requisito este plenamente alcançado, conforme MEMO. no. 88/2017-SCOM, de 3 de outubro de 2017, mencionado no Relatório.

7 CARVAlHO, Olavo. Viva Paulo Freire! Blog do Escola Sem Partido, 4 de junho 4 de 2012. Disponível em https://www.escolasempartido.org/blog/viva-paulo-freire/

8 Freire: o patrono da doutrinação. junho 4, 2012. Disponível em https://www.escolasempartido.org/blog/ freire-o-patrono-da-doutrinacao/. Matéria publicada originalmente no Jornal Diário de Cuiabá, edição de 29 de abril de 2012. Disponível em: http://www.diariodecuiaba.com.br/detalhe.php?cod=410434

9 Entrevista de Olavo de Carvalho a Luís Mauro Martino. Educação, julho de 1999. Disponível: https://olavodecarvalho.org/educacao-e-consciencia/

10 Texto derivado de conferência proferida no Seminário Internacional "Democracia em Colapso?", promovido pela editora Boitempo em parceria com o Sesc Pinheiros, em São Paulo no dia 15 de outubro de 2019. Ver: CHAUÍ, Marilena. Saiba mais - agência de reportagem. RAFAEL DUARTE, quarta-feira, 16 de outubro de 2019. Disponível em https://www.saibamais.jor.br/marilena-chaui-democracia-e-a-unica-sociedade-e-o-unico-regime-politico-que-considera-o-conflito-legitimo/ 


\section{Referências}

BRASIL. Decreto n 53.886, de 14 de abril de 1964. Revoga o Decreto n. 53.465, de 21 de janeiro de 1964, que instituiu o Programa Nacional de Alfabetização do Ministério da Educação e Cultura. Diário Oficial da União, Seção 1, 14/4/1964b, p. 3313 (Publicação Original).

BRASIL. Portaria $\mathrm{n}^{\mathbf{0}}$ 1, de 14 de abril de 1964. Determina a abertura de inquérito policial militar, a fim de apurar fatos e as devidas responsabilidades de todos aqueles que, no País, tenham desenvolvido ou ainda estejam desenvolvendo atividades capituláveis nas Leis que definem os crimes militares e os crimes contra o Estado e a Ordem Política e Social. Diário Oficial da União, Seção 1, 14/4/1964a, p. 3313 (Publicação Original).

BRASIL. Senado Federal. Parecer (SF) no 40, de 14 de dezembro de 2017. Relatório da Comissão de Direitos Humanos e Legislação Participativa, sobre o Sugestão n47, de 2017, que Revogação da Lei que institui Paulo Freire patrono da educação brasileira (Lei 12612).

CHAUÍ, Marilena. Comunicação e Democracia. In: Conferência Nacional Lula Livre: Vencer a Batalha da Comunicação. São Paulo, 13 e 14 de abril de 2020. Disponível em https://pt.org.br/marilena-chauicomunicacao-e-democracia/

CHAUÍ, Marilena. Saiba mais - agência de reportagem. 16 de outubro de 2019. Disponível em https:// www.saibamais.jor.br/marilena-chaui-democracia-e-a-unica-sociedade-e-o-unico-regime-politico-queconsidera-o-conflito-legitimo/

CHAUÍ, Marilena. Ideologia e educação. Educação e Pesquisa, São Paulo, v. 42, n. 1, p. 245-257, jan./mar. 2016.

FERNANDES, Florestan. Brasil, em compasso de espera. São Paulo: Hucitec, 1980.

FREIRE, Paulo. Educação como prática de liberdade. 7ª̣ ed. Rio de Janeiro: Paz e Terra, 1977.

FREIRE, Paulo. Pedagogia do oprimido. 16 $6^{\mathrm{a}}$ ed. Rio de Janeiro: Editora Paz e Terra, 1983.

FREIRE, Paulo. Ação cultural para a liberdade e outros escritos. 8ª ed. Rio de Janeiro: Paz e Terra, 1982.

FREIRE, Paulo; GUIMARÃES, Sérgio. Sobre educação: diálogos. Volume II, 2ª ed. Rio de Janeiro:

Editora Paz e Terra, 1984.

FREIRE, Paulo; BETTO, Frei. Essa escola chamada vida: depoimentos ao repórter Ricardo Kotscho. $4^{\mathrm{a}}$ ed. São Paulo: Editora Ática, 1986.

FREIRE, Paulo; SHOR, Ira. Medo e ousadia: o cotidiano do professor. Rio de Janeiro: Paz e Terra, 1986.

FREIRE, Paulo. Professora sim, tia não - cartas a quem ousa ensinar. $5^{\mathrm{a}}$ ed. São Paulo: Editora Olho d'Água, 1994.

FREIRE, Paulo. Pedagogia da Autonomia - saberes necessários à prática educativa. 15ª ed. São Paulo: Paz e Terra, 1996.

FRIGOTTO, Gaudêncio (org.). Escola "sem" partido: esfinge que ameaça a educação e a sociedade brasileira. Rio de Janeiro: UERJ, LPP, 2017.

HADDAD, Sergio. O educador: um perfil de Paulo Freire. São Paulo: Editora Todavia, 2019.

HADDAD, Sergio; DI PIERRO, Maria Clara. Escolarização de jovens e adultos. Rev. Bras. Educ., Rio de Janeiro n. 14, p. 108-130, mai./jun./jul./ago. 2000. 
LIMA, Licínio Carlos. Sobre a educação cultural e política dos professores. Educ. Rev., Curitiba, n. 61, p. 143-156, jul./set. 2016.

MACEDO, Elizabeth. As demandas conservadoras do movimento Escola Sem Partido e a Base Nacional Curricular Comum. Educação \& Sociedade, Campinas, v. 38, n. 139, p.507-524, abr./jun. de 2017.

MELLO, Guiomar Namo de. Social Democracia e Educação: teses para discussão. $2^{a}$ ed. São Paulo: Cortez/Autores Associados, 1990.

OLIVEIRA, Ana Cláudia Rodrigues de; STORTO, Letícia Jovelina; LANZA, Fabio. A educação básica brasileira em disputa: doutrinação versus neutralidade. Rev. katálysis, Florianópolis, v. 22, n. 3, p. 468478 , set. e 2019.

PENNA, Fernando. O ódio aos professores. In: SOUZA, A.L.S. et al. A ideologia da Escola sem Partido: 20 autores desmontam o discurso. São Paulo: Autores Associados, 2016.

SKLIAR, Carlos. Prólogo - Paulo Freire más que nunca una oportunidad entre lo inacabado y lo inacabable. In: KOHAN, Walter. Paulo Freire más que nunca: una biografia filosófica. $1^{a}$ edición. Ciudad Autónoma de Buenos Aires: CLACSO, 2020.

TEIXEIRA, Wagner da Silva. Golpe de 64 interrompeu alfabetização de adultos por dois anos. Bruno Bocchini. Repórter da Agência Brasil, São Paulo, 30 de maio de 2014. Disponível em https:// agenciabrasil.ebc.com.br/educacao/noticia/2014-05/golpe-de-64-interrompeu-alfabetizacao-de-adultospor-dois-anos-diz

TEIXEIRA, Wagner da Silva. Quando ensinar a ler virou subversão: a ditadura e o combate ao combate do analfabetismo. Disponível em: http://www.encontro2012.mg.anpuh.org/resources/ anais/24/1340763408_ARQUIVO_WagnerTeixeira_textocompleto.pdf

TOLEDO, Caio Navarro de. 1964: o golpe contra as reformas e a democracia. Rev. Bras. Hist. São Paulo, v. 24, n. 47, p. 13-28, 2004.

VASCONCELOS, Joana Salém. A escola, o autoritarismo e a emancipação. In: SOUZA, A. L. S. et al. A ideologia da Escola sem Partido: 20 autores desmontam o discurso. São Paulo: Autores Associados, 2016.

XIMENES, Salomão. O que o direito à educação tem a dizer sobre "escola sem partido"? In: SOUZA, A. L. S. et al. A ideologia da Escola sem Partido: 20 autores desmontam o discurso. São Paulo: Autores Associados, 2016.

XIMENES, Salomão; VICK, Fernanda. A extinção judicial do Escola sem Partido. Le Monde Diplomatique, Edição 156, 1 de julho de 2020, Brasil. Disponível em: https://diplomatique.org.br/aextincao-judicial-do-escola-sem-partido/ 